\title{
An extended X-ray absorption spectroscopy study of copper(II) sorption by oxides
}

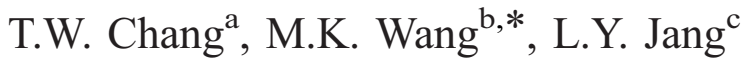 \\ ${ }^{a}$ Agricultural Engineering Research Center, Chungli 320, Taiwan, ROC \\ ${ }^{\mathrm{b}}$ Department of Agricultural Chemistry, National Taiwan University, Taipei 106, Taiwan, ROC \\ ${ }^{\mathrm{c}}$ National Synchrotron Radiation Research Center, Hsinchu 300, Taiwan
}

Received 14 October 2003; received in revised form 21 December 2004; accepted 6 January 2005

Available online 19 February 2005

\begin{abstract}
Many important sorption parameters have been determined by isothermal sorption batch experiments; however, only macroscopic and indirect results were obtained. The objective of this study was to derive the species and structural environment of $\mathrm{Cu}(\mathrm{II})$ on the surface of gibbsite $\left(\mathrm{Al}(\mathrm{OH})_{3}\right)$, pyrolusite $\left(\mathrm{MnO}_{2}\right)$, and amorphous silica $\left(\mathrm{SiO}_{2}\right)$, using the technique of extended X-ray Absorption Fine Structure (EXAFS) spectroscopy. Results show that the equilibrated pH of suspension affects significantly the species of $\mathrm{Cu}$ sorbed on the surface of these oxides. Sorbed species $\left(\mathrm{Cu}^{2+}\right)$ were present below pH 5.73 and precipitated $\left(\mathrm{Cu}(\mathrm{OH})_{2}\right)$ phases above 5.63. On the other hand, there is no EXAFS evidence that sorbent types and concentrations affect the local chemistry environment and species of $\mathrm{Cu}(\mathrm{II})$.
\end{abstract}

(C) 2005 Elsevier B.V. All rights reserved.

Keywords: $\mathrm{Al}(\mathrm{OH})_{3}$; Amorphous $\mathrm{SiO}_{2}$; Copper; $\mathrm{MnO} 2$; Extended X-ray Absorption Fine Structure (EXAFS); Sorption

\section{Introduction}

Isothermal sorption batch experiments are very important in soil science research. Theoretically, maximum monolayer sorption, empirical adsorption constants, and other important adsorption parameters can be determined by this method. Cation-exchange

\footnotetext{
* Corresponding author. Tel.: +88622363 0231x2491/3066; fax: +886223660751.

E-mail address: mkwang@ntu.edu.tw (M.K. Wang).
}

capacity (CEC) of soils and soil components can also be quantified. Mechanistic interpretations and models have been developed for metal sorption reactions at the soil/water interface; however, they are mostly been developed from macroscopic information without direct atomic-level evidence (Fendorf et al., 1994a, b; Farquhar et al., 1996; Dubbin et al., 2000). Moreover, reactions (particularly sorption reaction) at mineral-water interfaces are major factors in controlling the bioavailability, mobility, toxicity, and fate of added fertilizers, pesticides, herbicides, and pollutants in natural ecosystems (Sparks, 2002). 
According to aquatic chemistry, high solution concentrations or high $\mathrm{pH}$ may cause metal hydroxide or carbonate to precipitate unto mineral surfaces (Weesner and Bleam, 1997). Therefore, prediction models require thorough understanding of the composition of relevant surface species, such as identification of the exact species, where they bind to mineral surfaces, and the nature of their precipitate phases (Fitts et al., 1999).

X-ray absorption fine structure (XAFS) spectroscopy has proven to be a powerful method for obtaining the speciation and local structure of elements present in soils (Koningsberger and Prins, 1988; Fendorf and Sparks, 1996). Recent XAFS studies of $\mathrm{Cu}(\mathrm{II})$ sorption on mica (Charnock et al., 1995; Farquhar et al., 1996; Kriventsov et al., 1998), silica (Xia et al., 1997; Fitts et al., 1999; Kriventsov et al., 1999), clay minerals (Farquhar et al., 1996; Xia et al., 1997; Parkman et al., 1999; Manceau et al., 2000), and even in aqueous solution with humic substances (Angelo et al., 1998; Korshin et al., 1998; Dubbin et al., 2000; Frenkel et al., 2000; Alcacio et al., 2001) have examined the speciation and local structure of $\mathrm{Cu}(\mathrm{II})$. XAFS thereby offers local environmental information, which is unique among the currently available methods. In this study, three major soil components, gibbsite $\left(\mathrm{Al}(\mathrm{OH})_{3}\right)$, pyrolusite $\left(\mathrm{MnO}_{2}\right)$, and amorphous silica $\left(\mathrm{SiO}_{2}\right)$, were equilibrated with $\mathrm{Cu}$ (II) using isothermal sorption batch experiments. The objective of this study was to derive the species and structure environment of $\mathrm{Cu}$ (II) on the surface of these minerals using the technique of EXAFS spectroscopy.

\section{Methods and materials}

\subsection{Isothermal sorption of batch experiments}

The experiments were conducted using three commercial products, which are the most important components in soil, namely $\mathrm{Al}(\mathrm{OH})_{3}$ (gibbsite, Merck KGaA, Darmstadt; i.e., surface area of $1.5 \mathrm{~g}$ $\mathrm{m}^{-2},<1.7 \mu \mathrm{m}$ in size), $\mathrm{MnO}_{2}$ (pyrolusite, Aldrich Chemical Company; i.e., surface area of $2.0 \mathrm{~g} \mathrm{~m}^{-2}$, $<40 \mu \mathrm{m}$ in size), and $\mathrm{SiO}_{2}$ (amorphous silica, Cabot, Tuscolca, IL, i.e., surface area of $204 \mathrm{~g} \mathrm{~m}^{-2}, 15-25$ $\mathrm{nm}$ in diameter) (Kuan et al., 2004) equilibrated with
$\mathrm{Cu}$ (II) $\left(\mathrm{CuCl}_{2}\right.$ solution). Batch experiments were conducted by mixing 2 or $5 \mathrm{~g}$ of gibbsite, pyrolusite, and amorphous silica separately with $1 \mathrm{~L}$ of $0.5 \mathrm{mM}$ of $\mathrm{CuCl}_{2}$ solution in $1 \mathrm{~L}$ volumetric flasks. The background solution was $0.1 \mathrm{M} \mathrm{NaCl}$ electrolyte solution and the $\mathrm{pH}$ of the solution was adjusted to 5.5 and $6.5 \pm 0.1$ with $\mathrm{NaOH}$ and/or $\mathrm{HCl}$ solution at $25{ }^{\circ} \mathrm{C}$ using a Radiometer (Tim 865), titration manager in the set mode. The solution was stirred to achieve equilibrium at $25{ }^{\circ} \mathrm{C}$. After $16 \mathrm{~h}$, the equilibrium $\mathrm{pH}$ of the suspensions was measured and suspensions were filtered through a cellulose acetate membrane filter of size $0.22 \mu \mathrm{m}$. Copper concentrations in the clear supernatant were analyzed by Induced Couple Plasma (ICP-AES) (Perkin Elmer, Optima 3000).

\section{2. $\mathrm{Cu} \mathrm{K}$-edge XAFS spectroscopy}

XAFS spectroscopy was performed at the National Synchrotron Radiation Research Center (NSRRC), Science-Based Industrial Park, Hsinchu, Taiwan. X-ray absorption spectra at the $\mathrm{Cu} \mathrm{K}$-edge $(8979 \mathrm{eV})$ for each sample was collected at beam line (Wiggler-17C). The electron storage ring operated at $1.505 \mathrm{GeV}$ and the currents ranged from 80 to $200 \mathrm{~mA}$. Two parallel $\mathrm{Si}(111)$ crystals were used as a monochromator. All the spectra were recorded in fluorescence mode using two ionization chambers with argon as the detectors, which were positioned at $90^{\circ}$ to the incident beam. In order to prevent elastic and Compton scattering of the incident Xrays from entering the fluorescence detector, a nickel fluorescence filter ( $6 \mu \mathrm{x}$ equivalent) was used for scans at the Cu K-edge (Fendorf and Sparks, 1996). The $0.22 \mu \mathrm{m}$ cellulose acetate membrane filter with filtered sediments was placed at $45^{\circ}$ to the X-ray beam. At least three scans were collected for each sample and averaged to improve the signal-to-noise ratio. Each scan was 7-8 min. Energy calibration was monitored by placing a $\mathrm{Cu}$ foil behind the ionization chamber to measure the incident X-ray intensity. The first inflection point of the absorption $\mathrm{K}$-edge of the $\mathrm{Cu}$ foil was assigned the value of $8979 \mathrm{eV}$ and as the initial point $(k=0)$ of the EXAFS spectra. The EXAFS spectra were analyzed by UWXAFS 3.0 software package with phase and amplitude functions generated by FEFF8.10 (Anku- 
dinov and Rehr, 2000) to yield a radial structure function (RSF) and the curve fitting was performed for $k^{3}$-weighted $\chi(k)$ at the wave number interval $2.5-12.5 \AA^{-1}$. For the first shell fitting, the value of distance $(r \pm 0.02 \AA)$ and coordination number $(N \pm 20 \%)$ is provided (Sayers and Bunker, 1988; De Leon et al., 1991; Fendorf and Sparks, 1996; Fitts et al., 1999). Multiple backscattering effects were not considered in this study.

\section{Results and discussion}

\subsection{Batch experiments}

The sorbed amount of $\mathrm{Cu}$ on three minerals and equilibrated $\mathrm{pH}$ of batch experiments are shown in Table 1. The amount of $\mathrm{Cu}$ sorbed by gibbsite, pyrolusite, and amorphous silica ranged from 595 to $15462 \mu \mathrm{g} \mathrm{g}^{-1}, 10,557$ to $15,770 \mu \mathrm{g} \mathrm{g}^{-1}$, and 335 to $15418 \mu \mathrm{g} \mathrm{g}^{-1}$, respectively. The equilibrium $\mathrm{pH}$ of batch experiments ranged from 5.36 to 6.54 with the exception of an equilibrated $\mathrm{pH}$ of 8.86 present in pyrolusite suspension. In our study, with increasing $\mathrm{pH}$, the amounts of $\mathrm{Cu}$ sorbed on the surface of these three minerals increased. Only $4.4-67.0 \%$ of $\mathrm{Cu}$ added was removed from solution at $\mathrm{pH}$ below 5.63 , while $97.8-100.0 \%$ of $\mathrm{Cu}$ added was removed from solution at $\mathrm{pH}$ above 5.63. Meanwhile, the amount of $\mathrm{Cu}$ sorbed decreases proportionally with increasing amount of sorbents, meaning that the surface coverage decreases with increasing oxides.

Table 1

The sorbed amount of $\mathrm{Cu}$ on three minerals and equilibrium $\mathrm{pH}$ of batch experiments

\begin{tabular}{lllcl}
\hline Sorbent & $\begin{array}{l}\text { Sorbent } \\
\text { concentration } \\
\left(\mathrm{g} \mathrm{L}^{-1}\right)\end{array}$ & $\begin{array}{l}\text { Sorbed } \\
\text { amount } \\
\left(\mu \mathrm{g} \mathrm{g}^{-1}\right)\end{array}$ & $\begin{array}{l}\text { Removed } \\
\text { from solution } \\
(\%)\end{array}$ & $\begin{array}{l}\text { Equilibrium } \\
\mathrm{pH}\end{array}$ \\
\hline $\mathrm{Al}(\mathrm{OH})_{3}$ & 2 & 937 & 5.9 & 5.48 \\
& & 15,462 & 98.1 & 6.54 \\
& 5 & 595 & 9.4 & 5.36 \\
& & 6185 & 98.1 & 6.22 \\
$\mathrm{MnO}_{2}$ & 2 & 10,557 & 67.0 & 5.63 \\
$\mathrm{SiO}_{2}$ & 2 & 15,770 & 100.0 & 8.86 \\
& & 687 & 4.4 & 5.60 \\
& 5 & 15,418 & 97.8 & 6.25 \\
& & 335 & 5.3 & 5.54 \\
& & 6165 & 97.8 & 6.43
\end{tabular}

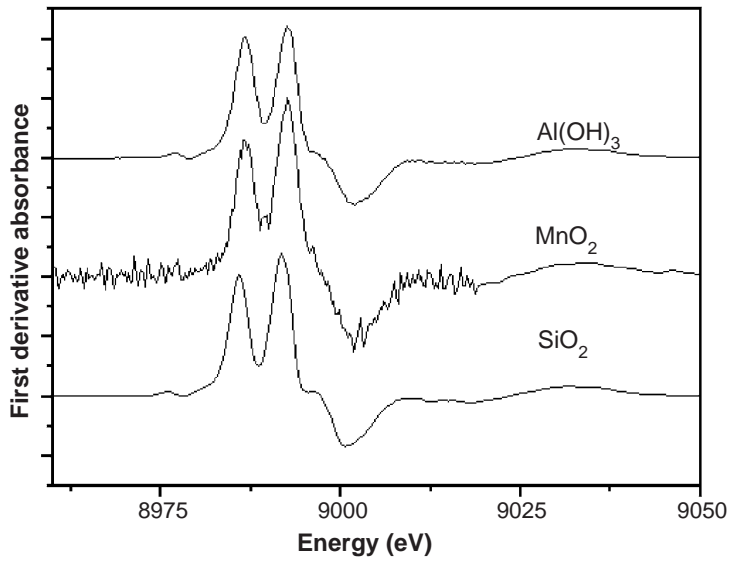

Fig. 1. The first derivatives of $\mathrm{Cu}(\mathrm{II}) \mathrm{K}$-edge XANES spectra of three representative samples.

Similar trends have also been reported previously (Chang et al., 2002).

\subsection{XANES spectra analysis}

Fig. 1 shows the first derivatives of K-edge XANES spectra of three representative samples and the pre-edge peak, indicating the first inflection point of the absorption K-edge of $\mathrm{Cu}(8979 \mathrm{eV})$. XANES spectra of both octahedral and tetrahedral metal complexes possess the pre-edge peak and its intensity increases with distortion, which removes the symmetric center and results in $d-p$ orbital mixing (Lytle et al., 1988; Xia et al., 1997). On the other hand, each first derivative spectrum also shows obvious split peaks in Fig. 1, revealing that there is a strong shoulder structure in the region half-way up the edge due to $1 s-4 p$ transitions (Bianconi et al., 1982). $\mathrm{Cu}$ (II) has nine $3 \mathrm{~d}$ electrons, with a low probability for that bound state transition, so the pre-edge is always small but its size will depend on the degree of distorted. It will be smallest symmetrical octahedral, larger for distorted octahedral, and largest for tetrahedral. The shoulder on the edge step has been attributed to multiple low scattering effects (Strange et al., 1990). Miessler and Tarr (1991) also demonstrate that $\mathrm{Cu}(\mathrm{II})$ commonly shows significant Jahn-Teller effects which may cause the structure of $\mathrm{Cu}$ (II) complex to vary from tetrahedral through square planar to distorted octahedral. Therefore, the binding structure of $\mathrm{Cu}(\mathrm{II})$ in the samples studied is likely to be 
tetragonal-distorted octahedral (Xia et al., 1997; Fitts et al., 1999; Dubbin et al., 2000; Manceau et al., 2000).

\subsection{EXAFS spectra analysis}

The normalized and background-subtracted $k^{3}$ weighted $\chi(k)$ curves of six representative samples are shown in Fig. 2. EXAFS spectra oscillations are due to photoelectron scattering from atoms surrounding the target of $\mathrm{Cu}$ (II) ion. At equilibrated $\mathrm{pH}$ of suspension below 5.63, samples $\mathrm{A}$ and $\mathrm{E}$ show the same amplitude, frequency, and phase for each EXAFS spectrum. This indicates that the local chemical environment of $\mathrm{Cu}$ (II) in these two samples is very similar even though the sorbent types and concentrations are different. On the other hand, at $\mathrm{pH}$ above 5.63, samples $\mathrm{B}, \mathrm{C}, \mathrm{D}$, and $\mathrm{F}$ all show strong similarities in their EXAFS spectra, but are distinguished from samples $A$ and $E$ by an extra peak at $k=7.6-7.8$. This peak seems to be characteristic of the type of $\mathrm{Cu}$ environment in $\mathrm{Cu}(\mathrm{OH})_{2}$ (e.g., compared with EXAFS spectra of Fitts et al. (1999) and Xia et al. (1997)). Therefore, the local structural environments surrounding $\mathrm{Cu}$ are different at equilibrated $\mathrm{pH}$ of suspension below or above 5.63. According to solution equilibrium calculations using equilibrium constants (Lindsay, 1979; Smith and Martell, 1976), Harter (1983) indicates that free $\mathrm{Cu}^{2+}$ is the dominant species $(>96 \%)$ in the solution at $\mathrm{pH}$

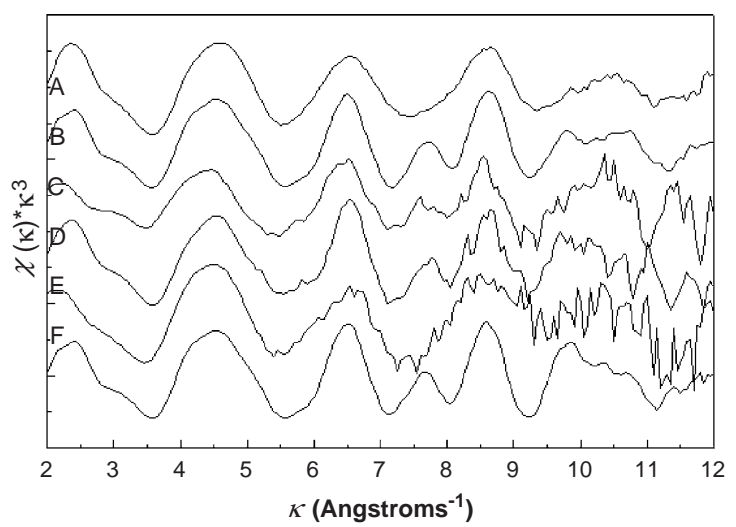

Fig. 2. Normalized and background-subtracted $k^{3}$-weighted EXAFS spectra of (A) $2 \mathrm{~g} \mathrm{~L}^{-1} \mathrm{Al}(\mathrm{OH})_{3}, \mathrm{pH} 5.32$, (B) $5 \mathrm{~g} \mathrm{~L}^{-1} \mathrm{Al}(\mathrm{OH})_{3}, \mathrm{pH}$ 6.22, (C) $2 \mathrm{~g} \mathrm{~L}^{-1} \mathrm{MnO}_{2}$, pH 5.63, (D) $2 \mathrm{~g} \mathrm{~L}^{-1} \mathrm{MnO}_{2}, \mathrm{pH} 8.86$, (E) $5 \mathrm{~g} \mathrm{~L}^{-1} \mathrm{SiO}_{2}$, pH 5.54, and (F) $2 \mathrm{~g} \mathrm{~L}^{-1} \mathrm{SiO}_{2}, \mathrm{pH} 6.25$. below 6.0, while both free $\mathrm{Cu}^{2+}$ and $\mathrm{Cu}(\mathrm{OH})_{2}{ }^{\circ}$ are the predominant species and $\mathrm{CuOH}^{+}$is the minor species $(2-7 \%)$ at $\mathrm{pH} 6-7$. For solution with $\mathrm{pH}$ above 8.0, $\mathrm{Cu}(\mathrm{II})$ exists as $\mathrm{Cu}(\mathrm{OH})_{2}{ }^{\circ}(>92 \%)$. However, McBride and Blasiar (1979) demonstrated that increase in total $\mathrm{Cu}(\mathrm{II})$ at higher $\mathrm{pH}$ was not accompanied by an activity increase, indicating that most of the $\mathrm{Cu}(\mathrm{II})$ (around $17 \%$ of total soluble $\mathrm{Cu}^{2+}$ ) was in complexed form above $\mathrm{pH}$ 5.0. In addition, the EXAFS study of Xia et al. (1997) reported polynuclear copper hydroxide clusters precipitated on silica surface during the sorption process with equilibrated $\mathrm{pH}$ at 5.5 and low surface coverage ( $0.8 \%$ of a monolayer). Fig. 3 shows the EXAFS spectra of $\mathrm{Cu}$ (II) sorbed on gibbsite, pyrolusite, and amorphous silica under different $\mathrm{pH}$ conditions. It reveals that the local chemical structure of $\mathrm{Cu}$ (II) would change at equilibrium $\mathrm{pH}$ greater than 5.6 (gibbsite system), 5.6 (pyrolusite system, Fig. 2), or 5.7 (amorphous silica system). Therefore $\mathrm{Cu}(\mathrm{OH})_{2}{ }^{\circ}$ may exist as the main sorbed species for solutions with $\mathrm{pH}$ greater than 5.6.

The radial structure function (RSF) of $\mathrm{Cu}$ (II) sorbed by three oxides, together with the best fit of the Fourier transforms of the EXAFS spectra (uncorrected for phase shift), at different $\mathrm{pH}$ and sorbent concentrations are shown in Fig. 4. The structure parameters of best fits are summarized in Table 2. At equilibrium $\mathrm{pH}$ below 5.63, the best fits for $\mathrm{Cu}$ on both gibbsite and amorphous silica samples show four nearest $\mathrm{O}$ atoms (i.e., coordination number is 4.0 ) at the distance of $1.98-2.04 \AA$ and 1.92-2.00 $\AA$ completing the first coordination sphere, respectively. Schofield et al. (1994) and Alcacio et al. (2001) reported that the longer distance is partly due to scattering from the two longer apical oxygen. Coordination numbers for distorted sites are often anomalously small. In Table 2, the best fit data also show that there are two more shells with one and four coordination numbers at the distances of 2.65 and $3.34 \AA$, respectively. The second shell distance of $2.65 \AA$ is consistent with the local structure of plancheite, $\mathrm{Cu}_{8}\left(\mathrm{Si}_{4} \mathrm{O}_{11}\right)_{2}(\mathrm{OH})_{4}\left(\mathrm{H}_{2} \mathrm{O}\right)$, and shattuckite, $\mathrm{Cu}_{5}\left(\mathrm{SiO}_{3}\right)_{4}(\mathrm{OH})_{2}$ previously reported (Farquhar et al., 1996). The $\mathrm{Cu}$ on this shell is bridged by two oxygen atoms to form "ribbons" of oxygen bridged chain and this $\mathrm{Cu}-\mathrm{Cu}$ distance is very short due to constriction by the 

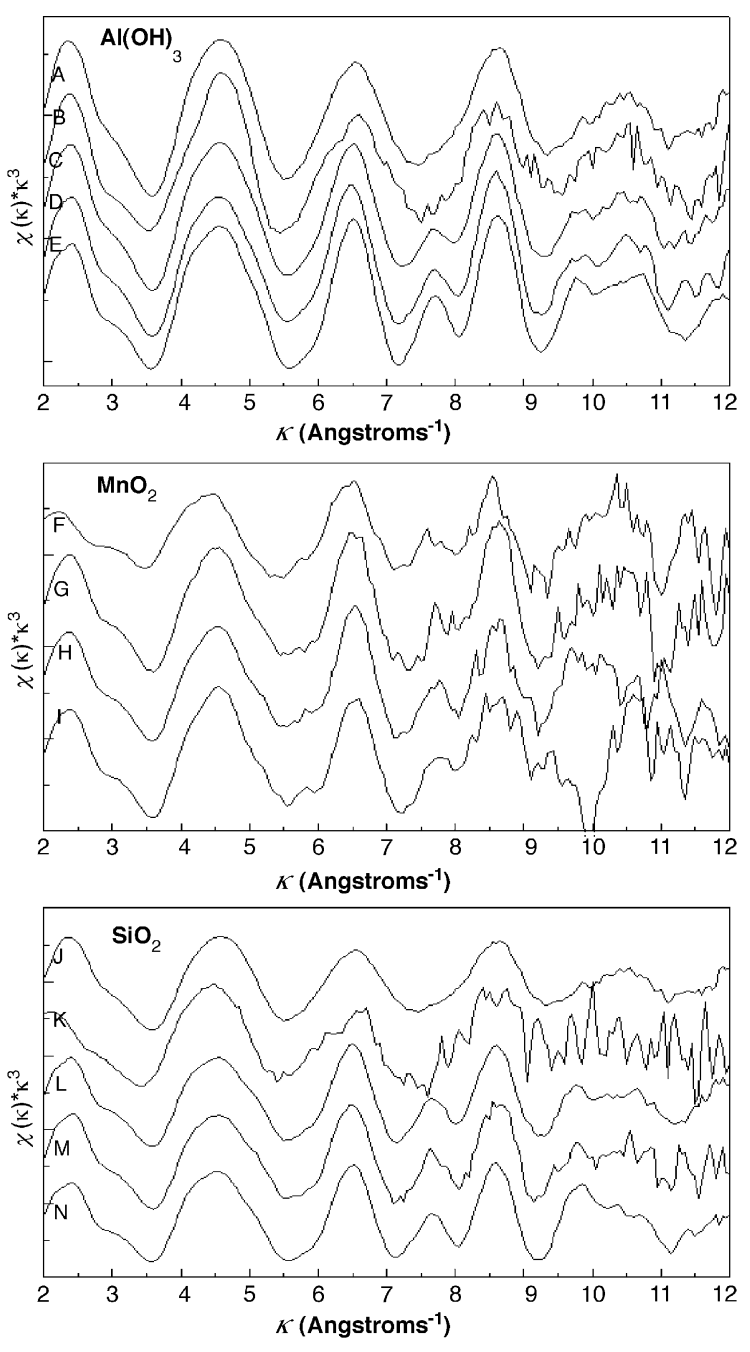

Fig. 3. Effect of $\mathrm{pH}$ on EXAFS spectra of $\mathrm{Cu}(\mathrm{II})$ sorbed on $\mathrm{Al}(\mathrm{OH})_{3}$ at (A) $\mathrm{pH} 5.32$, (B) $\mathrm{pH} 5.48$, (C) $\mathrm{pH} 5.70$, (D) $\mathrm{pH} 6.54$, (E) $\mathrm{pH} 6.54$; on $\mathrm{MnO}_{2}$ at (F) pH 5.63, (G) pH 7.60, (H) pH 8.86, (I) pH 9.12; and on $\mathrm{SiO}_{2}$ at (J) pH 5.54, (K) pH 5.60, (L) pH 5.87, (M) pH 5.98, (N) pH 6.25 .

surrounding aluminosilicate matrix (Charnock et al., 1995; Farquhar et al., 1996). Therefore, the $\mathrm{Cu}$ of this second shell is consistent with a sorbed $\mathrm{Cu}$ species with this type of structure. The third shell may be attributed to either $\mathrm{Cu}$ or the center atom of sorbent ( $\mathrm{Al}$ or $\mathrm{Si}$ ), because their backscattering properties are too similar to allow distinction (Parkman et al., 1999). On the other hand, at equilibrium $\mathrm{pH}$ above 5.63, $\mathrm{Cu}(\mathrm{OH})_{2}{ }^{\circ}$ exists in all samples. The best fits for $\mathrm{Cu}$ on all samples are the same as those for $\mathrm{pH}$ below 5.63; however, an extra shell, with coordination numbers close to 2.0 at the distance of $2.95 \AA$, is found. This shell is attributed to the backscattering of $\mathrm{Cu}$ in $\mathrm{Cu}(\mathrm{OH})_{2}{ }_{2}^{\circ}$. This indicates that both sorbed $\left(\mathrm{Cu}^{2+}\right)$ and precipitated $\left(\mathrm{Cu}(\mathrm{OH})_{2}\right)$ species exist on oxides at $\mathrm{pH}$ above 5.63. Meanwhile, all evidence shows that
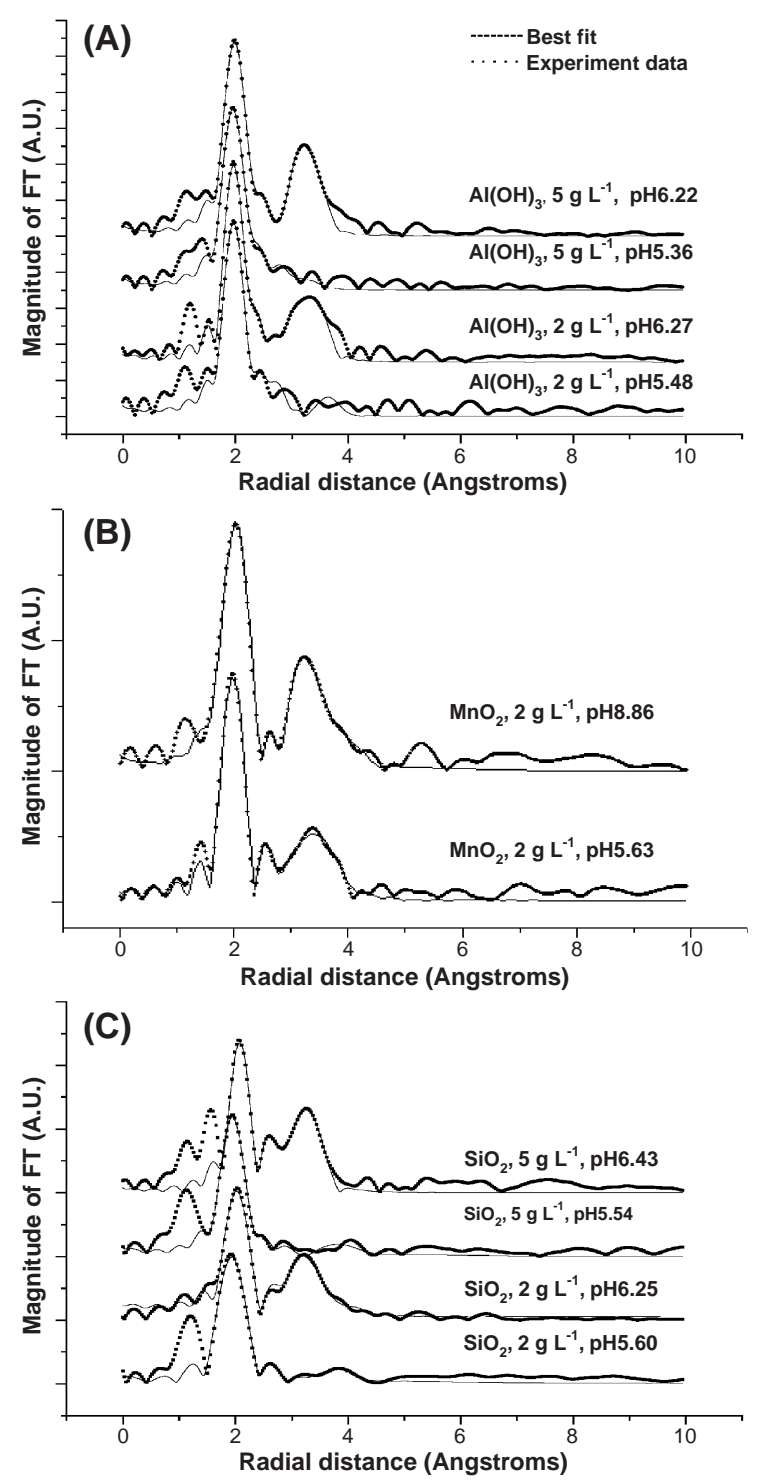

Fig. 4. Radial structure function (RSF) and best fit of $\mathrm{Cu}(\mathrm{II})$ sorbed on (A) $\mathrm{Al}(\mathrm{OH})_{3},(\mathrm{~B}) \mathrm{MnO}_{2}$, and (C) $\mathrm{SiO}_{2}$ along with Fourier transforms of the EXAFS spectra (uncorrected for phase shift). 
Table 2

Atoms, coordination numbers $(N)$, bond distances $(r)$, Debye-Waller factors $\left(\sigma^{2}\right)$, and $R$-factors obtained from the curve fitting procedure for the local $\mathrm{Cu}$ surrounding

\begin{tabular}{|c|c|c|c|c|c|c|c|}
\hline Sorbent & $\begin{array}{l}\text { Sorbent conc. } \\
\left(\mathrm{g} \mathrm{L}^{-1}\right)\end{array}$ & $\begin{array}{l}\text { Equilibrium } \\
\mathrm{pH}\end{array}$ & Atom & $r(\AA)$ & $N$ & $\sigma^{2}\left(\AA^{2}\right)$ & $\begin{array}{l}\text { (R)-factor* } \\
(\%) \\
\end{array}$ \\
\hline \multirow[t]{14}{*}{$\mathrm{Al}(\mathrm{OH})_{3}$} & \multirow[t]{7}{*}{2} & \multirow[t]{3}{*}{5.48} & $\mathrm{O}$ & 2.04 & 4.0 & 0.005 & \multirow[t]{3}{*}{1.32} \\
\hline & & & $\mathrm{Cu}$ & 2.64 & 1.2 & 0.015 & \\
\hline & & & $\mathrm{Cu} / \mathrm{Al}$ & 3.30 & 4.5 & 0.019 & \\
\hline & & \multirow[t]{4}{*}{6.54} & $\mathrm{O}$ & 1.96 & 4.0 & 0.003 & \multirow[t]{4}{*}{0.12} \\
\hline & & & $\mathrm{Cu}$ & 2.65 & 1.0 & 0.009 & \\
\hline & & & $\mathrm{Cu}$ & 2.95 & 2.0 & 0.006 & \\
\hline & & & $\mathrm{Cu} / \mathrm{Al}$ & 3.34 & 4.0 & 0.008 & \\
\hline & \multirow[t]{7}{*}{5} & \multirow[t]{3}{*}{5.36} & $\mathrm{O}$ & 1.98 & 4.0 & 0.005 & \multirow[t]{3}{*}{1.16} \\
\hline & & & $\mathrm{Cu}$ & 2.62 & 1.2 & 0.020 & \\
\hline & & & $\mathrm{Cu} / \mathrm{Al}$ & 3.36 & 4.8 & 0.022 & \\
\hline & & \multirow[t]{4}{*}{6.22} & $\mathrm{O}$ & 1.95 & 4.0 & 0.005 & \multirow[t]{4}{*}{0.17} \\
\hline & & & $\mathrm{Cu}$ & 2.65 & 1.1 & 0.019 & \\
\hline & & & $\mathrm{Cu}$ & 3.01 & 2.0 & 0.011 & \\
\hline & & & $\mathrm{Cu} / \mathrm{Al}$ & 3.27 & 4.0 & 0.008 & \\
\hline \multirow[t]{8}{*}{$\mathrm{MnO}_{2}$} & \multirow[t]{8}{*}{2} & \multirow[t]{4}{*}{5.63} & $\mathrm{O}$ & 1.97 & 4.0 & 0.001 & \multirow[t]{4}{*}{0.34} \\
\hline & & & $\mathrm{Cu}$ & 2.60 & 1.0 & 0.006 & \\
\hline & & & $\mathrm{Cu}$ & 2.93 & 2.1 & 0.002 & \\
\hline & & & $\mathrm{Cu} / \mathrm{Mn}$ & 3.28 & 4.2 & 0.000 & \\
\hline & & \multirow[t]{4}{*}{8.86} & $\mathrm{O}$ & 1.97 & 4.0 & 0.008 & \multirow[t]{4}{*}{0.23} \\
\hline & & & $\mathrm{Cu}$ & 2.65 & 1.0 & 0.010 & \\
\hline & & & $\mathrm{Cu}$ & 2.95 & 2.0 & 0.006 & \\
\hline & & & $\mathrm{Cu} / \mathrm{Mn}$ & 3.34 & 4.0 & 0.016 & \\
\hline \multirow[t]{14}{*}{$\mathrm{SiO}_{2}$} & \multirow[t]{7}{*}{2} & \multirow[t]{3}{*}{5.60} & $\mathrm{O}$ & 2.00 & 4.0 & 0.004 & \multirow[t]{3}{*}{0.41} \\
\hline & & & $\mathrm{Cu}$ & 2.63 & 1.3 & 0.038 & \\
\hline & & & $\mathrm{Cu} / \mathrm{Si}$ & 3.32 & 4.1 & 0.021 & \\
\hline & & \multirow[t]{4}{*}{6.25} & $\mathrm{O}$ & 1.96 & 4.0 & 0.003 & \multirow[t]{4}{*}{0.68} \\
\hline & & & $\mathrm{Cu}$ & 2.64 & 1.2 & 0.017 & \\
\hline & & & $\mathrm{Cu}$ & 2.90 & 2.0 & 0.003 & \\
\hline & & & $\mathrm{Cu} / \mathrm{Si}$ & 3.36 & 3.8 & 0.013 & \\
\hline & \multirow[t]{7}{*}{5} & \multirow[t]{3}{*}{5.54} & $\mathrm{O}$ & 1.92 & 4.0 & 0.006 & \multirow[t]{3}{*}{0.87} \\
\hline & & & $\mathrm{Cu}$ & 2.66 & 1.0 & 0.026 & \\
\hline & & & $\mathrm{Cu} / \mathrm{Si}$ & 3.31 & 5.0 & 0.026 & \\
\hline & & \multirow[t]{4}{*}{6.43} & $\mathrm{O}$ & 1.95 & 4.1 & 0.014 & 0.71 \\
\hline & & & $\mathrm{Cu}$ & 2.65 & 1.0 & 0.002 & \\
\hline & & & $\mathrm{Cu}$ & 2.95 & 2.0 & 0.005 & \\
\hline & & & $\mathrm{Cu} / \mathrm{Si}$ & 3.34 & 4.0 & 0.005 & \\
\hline
\end{tabular}

\footnotetext{
* $R$-factor is the overall goodness-of-fit.
}

there is no significant effect of sorbent types and sorbent concentrations on the EXAFS spectra.

\section{Conclusions}

$\mathrm{Cu}(\mathrm{II})$ was reacted with three important soil components-gibbsite, pyrolusite, and amorphous silica at different equilibrated $\mathrm{pH}$ and sorbent concentrations. The $\mathrm{pH}$ significantly affects the species of $\mathrm{Cu}$ sorbed on the surface of these oxides. At equilibrated $\mathrm{pH}$ of suspensions below 5.63, the sorbed species of $\mathrm{Cu}$ with the best-fits bond distance and coordination number are as follows: $\mathrm{Cu}-\mathrm{O}, 1.95 \AA$ and 4 ; $\mathrm{Cu}-\mathrm{Cu}, 2.65 \AA$ and 1 ; and $\mathrm{Cu}-\mathrm{Cu} / \mathrm{M}(\mathrm{M}$ is the center atom of sorbent, $\mathrm{Al}, \mathrm{Mn}$, or $\mathrm{Si}$ in this study), 3.34 and 4 . On the other hand, at equilibrated $\mathrm{pH}$ of suspension above $5.63, \mathrm{Cu}(\mathrm{OH})_{2}{ }^{\circ}$ was the major species present in the solution, therefore, both adsorbed and precipitated species might exist on the surface of oxides. The best-fit bond distances and coordination numbers were as follows: $\mathrm{Cu}-\mathrm{O}, 1.95 \AA$ 
and 4; $\mathrm{Cu}-\mathrm{Cu}, 2.65 \AA$ and $1 ; \mathrm{Cu}-\mathrm{Cu}, 2.95 \AA$ and 2; and $\mathrm{Cu}-\mathrm{Cu} / \mathrm{M}, 3.34 \AA$ and 4 . According to the EXAFS spectra and the results of best fit, there is no significant difference between the three oxides and the two sorbent concentrations.

\section{Acknowledgments}

This research was funded through project $85 \mathrm{SAT}$ 1.21-FAD-12(3) of the Council of Agriculture and NSC89-2621-B-002-006 of the National Science Council, Republic of China. We thank Mr. ChenShan Pong for sample preparation and Dr. Jyh-Fu Lee, Dr. Ming-Chieng Hsiou and Dr. Horng-Paul Wang of Department of Environmental Engineering, National Cheng Kong University, for data analysis assistance.

\section{References}

Alcacio, T.E., Hesterberg, D., Chou, J.W., Martin, J.W., Beauchemin, S., Sayers, D.E., 2001. Molecular scale characteristics of $\mathrm{Cu}(\mathrm{II})$ bonding in goethite-humate complexes. Geochim. Cosmochim. Acta 65, 1355-1366.

Angelo, P.D., Bottari, E., Festa, M.R., Nolting, H.-F., Pavel, N.V., 1998. X-ray absorption study of copper(II)-glycinate complexes in aqueous solution. J. Phys. Chem., B 102, 3114-3122.

Ankudinov, A.I., Rehr, J.J., 2000. Theory of solid state contributions to the X-ray elastic scattering amplitude. Phys. Rev., B Condens. Matter 62, 2437.

Bianconi, A., Dell, A.M., Durham, P.J., Pendry, J.B., 1982. Multiple-scattering resonances and structural effects in the $\mathrm{X}$ ray-absorption near-edge spectra of Fe II and Fe III hexacyanide complexes. Phys. Rev., B Condens. Matter 26 (12), $6502-6508$.

Chang, T.W., Wang, M.K., Lin, C., 2002. Adsorption of copper in the different sorbent/water ratios of soil systems. Water Air Soil Pollut. 138, 199-209.

Charnock, J.M., England, K.E.R., Farquhar, M.L., Vaughan, D.L., 1995. A REFLEXAFS study of metal adsorption on a mica surface. Physica, B + C 208 \& 209, 457-458.

de Leon, M.J., Rehr, J.J., Zabinsky, S.I., Albers, R.C., 1991. Ab initio curved-wave X-ray-absorption fine structure. Phys. Rev., B 44, 4146-4156.

Dubbin, W.E., Sposito, G., Zavarin, M., 2000. X-ray absorption spectroscopic study of Cu-glyphosate adsorbed by microcrystalline gibbsite. Soil Sci. 165, 699-707.

Farquhar, M.L., Charnock, J.M., England, K.E.R., Vaughan, D.J., 1996. Adsorption of $\mathrm{Cu}(\mathrm{II})$ on the (001) plane of mica: a REFLEXAFS and XPS study. J. Colloid Interface Sci. 177, $561-567$.
Fendorf, S.E., Sparks, D.L., 1996. X-ray absorption fine structure spectroscopy. In: Page, A.L. (Ed.), Methods of Soil Analysis: Part 3. Chemical Methods, Soil Sci. Soc. Am. J., pp. 337-416. Madison, WI.

Fendorf, S.E., Lamble, G.M, Stapleton, M.G., Kelley, M.J., Sparks, D.L., 1994a. Mechanisms of chromium(III) sorption on silica: I. Cr(III) surface structure derived by extended X-ray absorption fine structure (EXAFS) spectroscopy. Environ. Sci. Technol. 28, 284-289.

Fendorf, S.E., Sparks, D.L., Lamble, G.M., Kelley, M.J., 1994b. Application of X-ray absorption fine structure spectroscopy to soils. Soil Sci. Soc. Am. J. 58, 1583-1595.

Fitts, J.P., Trainor, T.P., Grolimund, D., Bargar, J.R., Parks, G.A., Brown Jr., G.E., 1999. Grazing-incidence XAFS investigations of $\mathrm{Cu}$ (II) sorption products at $\alpha-\mathrm{Al}_{2} \mathrm{O}_{3}-$ water and $\alpha-\mathrm{SiO}_{2}$-water interfaces. J. Synchrotron Radiat. 6, 627-629.

Frenkel, A.I., Korshin, G.V., Ankudinov, A.L., 2000. XANES study of $\mathrm{Cu}^{2+}$-binding sites in aquatic humic substances. Environ. Sci. Technol. 34, 2138-2142.

Harter, R.D., 1983. Effect of soil pH on adsorption of lead, copper, zinc, and nickel. Soil Sci. Soc. Am. J. 47, 47-51.

Koningsberger, D.C., Prins, R., 1988. X-ray Absorption. Principles, Applications, Techniques of EXAFS, SEXAFS, and XANES. John Wiley and Sons, New York.

Korshin, G.V., Frenkel, A.I., Stern, E.A., 1998. EXAFS study of the inner shell structure in copper(II) complexes with humic substances. Environ. Sci. Technol. 32, 2699-2705.

Kriventsov, V.V., Elizarova, G.L., Kochubey, D.I., 1998. An EXAFS study of the amorphous cuprum hydroxide. Nucl. Instrum. Methods Phys. Res. A405, 341-343.

Kriventsov, V.V., Kochubey, D.I., Elizarova, G.L., Matvienko, L.G., Parmon, V.N., 1999. The structure of amorphous bulk and silica-supported copper(II) hydroxides. J. Colloid Interface Sci. 215, 23-27.

Kuan, W.H., Lo, S.L., Wang, M.K., 2004. Modeling and electrokinetic evidences on the processes of the $\mathrm{Al}(\mathrm{III})$ sorption continuum in $\mathrm{SiO}_{2(\mathrm{~s})}$ suspension. J. Colloid Interface Sci. 272, 489-497.

Lindsay, W.L., 1979. Chemical Equilibria in Soils. John Wiley and Sons, New York.

Lytle, F.W., Greegor, R.B., Panson, A.J., 1988. Discussion of X-rayabsorption near-edge structure-application to $\mathrm{Cu}$ in the high- $\mathrm{T}_{\mathrm{c}}$ superconductors $\mathrm{La}_{1.8} \mathrm{Sr}_{0.2} \mathrm{CuO}_{4}$ and $\mathrm{Ba}_{2} \mathrm{Cu}_{3} \mathrm{O}_{7}$. Phys. Rev., B Condens Matter 37 (4), 1550-1562.

Manceau, A., Schlegel, M.L., Musso, M., Sole, V.A., Gauthier, C., Petit, P.E., Trolard, 2000. Crystal chemistry of trace elements in natural and synthetic goethite. Geochim. Cosmochim. Acta 64, 3643-3661.

McBride, M.B., Blasiar, J.J., 1979. Zinc and copper solubility as a function of $\mathrm{pH}$ in an acid soil. Soil Sci. Soc. Am. J. 43, $866-870$.

Miessler, G.L., Tarr, D.A., 1991. Inorganic Chemistry. Prentice-Hall Inc., New York.

Parkman, R.H., Charnock, J.M., Bryan, N.D., Livens, F.R., Vaughan, D.J., 1999. Reactions of copper and cadmium ions in aqueous solution with goethite, lepidocrocite, mackinawite, and pyrite. Am. Mineral. 84, 407-419. 
Sayers, D.E., Bunker, B.A., 1988. Data analysis. In: Winefordner, J.D., Kolthoff, I.M. (Eds.), Chemical Analysis. John Wiley and Sons, New York, pp. 211-253. Chapter 6.

Schofield, P.F., Charnock, J.M., Gressey, G., Henderson, C.M.B., 1994. An EXAFS study of cation site distortions through the P2/ c-P $\overline{1}$ phase transition in the synthetic cuproscheelite-sanmartinite solid solution. Mineral. Mag. 58, 185-199.

Smith, R.M., Martell, A.E., 1976. Critical Stability Constants. Inorganic Complexes, vol. 4. Plenum Press, New York.

Sparks, D.L., 2002. Environmental Soil Chemistry. Academic Press, New York.

Strange, R.W., Alagna, L., Durham, P., Hasnain, S.S., 1990. An understanding of X-ray absorption near-edge structure of
copper(II) imidazole complexes. J. Am. Chem. Soc. 112, 4265-4268.

Weesner, F.J., Bleam, W.F., 1997. X-ray absorption and EPR spectroscopic characterization of adsorbed copper(II) complexes at the boehmite $(\mathrm{AlOOH})$ surface. J. Colloid Interface Sci. 196, $79-86$.

Xia, K., Mehadi, A., Taylor, R.W., Bleam, W.F., 1997. X-ray absorption and electron paramagnetic resonance studies of $\mathrm{Cu}$ (II) sorbed to silica: surface-induced precipitation at low surface coverages. J. Colloid Interface Sci. 185, 252-257. 